\title{
Causality between Financial Development and Economic Growth in Nepal
}

\author{
Rajendra Maharjan *
}

\begin{abstract}
This study examines the empirical relationship between financial development and economic growth in Nepal. Financial development has been measured by three key pillars of the financial system bank, capital market and insurance. Gross domestic product and gross fixed capital formation are considered for economic growth indicators. Using time series techniques, the stationary properties of the data sets are tested followed by Johansen co-integration test to observe long run equilibrium relationship between the two variables and Granger Causality test to identify the causal relationship among the variables. Also, Vector Error Correction Model (VECM) has been employed to analyze the short run dynamics of the system.

The result of the study reveals that there is cointegrating relationship between market capitalization and economic development with short-run causality is running from market capitalization to GDP. In regard to insurance market, error correction term is negative and significance for both GDP and GCF indicating there is cointegrating relationship between insurance market and economic development. However, the result shows no evidence of causality between insurance premium and economic development in short-run. The negative relation between bank and GDP reinforces that there is a cointegrating relationship between banking sector development and economic development. The result also shows that lagged value of GDP is significant. It shows that short-run causality is running from GDP to banking sector development.
\end{abstract}

Key Words: Gross Domestic Product (GDP), Market Capitalization, Gross fixed Capital formation, Private Credit, Insurance Premium (IP)

\section{JEL Classification:}

* PhD Scholar, Midwestern University 


\section{INTRODUCTION}

The relationship between financial development and economic growth has remained important issue of debate as considerable empirical studies conducted in different countries produce contrasting the results(Ginevičius, Dudzevičiūtè, Schieg, \& Peleckis, 2019). The study of the relationship between financial development and economic growth can be traced back in early 19th century by the work of Schumpeter (1911) who argued that financial services are dominant in promoting economic growth. Later, the attention towards exploring the issues related to financial development on the process of economic growth seems to have getting attention during 1960s and 1970s. The later works of economist like Goldsmith (1969), McKinnon (1973) and Shaw (1973) shown that the topic had drawn the attention and interest of many economists of modern times and had threw some light on this issues. But it was the findings of a study by King and Levine (1997) that has thrived to generate considerable research into this relationship. The studies explore two questions major issues finance-growth nexus, namely: the correlation between financial development and economic growth; and the direction of causality between financial development and economic growth.

Patrick (1966) posited that the direction of causation could either run from demand following phenomenon (economic development) to supply leading phenomenon (financial development). or it could run from financial development to economic development (supply-leading phenomenon). Patrick's concludes that financial development was likely to be predominant in the early stages of development and then as the economy develops the demand-following phenomenon begins to gain prominence (p. 177). Graff (1999) study concludes that financial development and economic growth is not causally related. On the one hand, growth provides the ability and acts as a catalyst for the development of the financial structure (Demetriades and Hussein, 1996). In this study an initiative is undertaken to find out which of the above arguments hold good in case of financial development and economic growth in Nepalese context.

Generally, there are four contrasting empirically proven theory behind the financial development and economic growth. The supply-leading hypothesis, demand-following hypothesis, bidirectional-causality view and the fourth view stipulating that financial development and economic growth have no causal relationship(Nyasha \& Odhiambo, 2015). The supply leading hypothesis claims that the development of financial sector as the precondition for economic growth(Bayar, Kaya, \& Yildirim, 2014). The demand following hypothesis claims that growth instigates the demand for financial commodities(Bnwumere, Ibe, Okafor, \& Uche, 2012). The bi-directional causality hypothesis stipulates that financial progression and economic growth are bi-directionally causal while the 
fourth view states that financial progression has no relationship with economic growth (Nyasha \& Odhiambo, 2015).

Most of the studies conducted to evaluate the causal relationship between bank and stock related financial development without considering insurance sector. (Boon, 2005)recommends three key elements of financial market development as bank, capital market and insurance. This study considered all those three-key components. Stock market is considered as an indication of market capitalization while insurance market development has been measured by premium collection rather than the insurance funds and investment. Similarly, as per the most of the empirical study considering Gross Domestic Product (GDP) as an economic development indicator and gross fixed capital formation.

Based on the brief introduction, the study aims to explore the causality between financial development and economic growth of Nepal. Section two provides a discussion of the theoretical foundation and the empirical evidence. Section three highlights the methodology followed by measurement of data and empirical finding in section four. The last section five presents concludes with the implications of the study.

\section{THEORETICAL DISCUSSION AND EMPIRICAL EVIDENCE}

Several theory related to economic growth have been developed over the period such as economic development by Robinson (1952), the growth model by Solow (1956), Lucas (1988)finance theory, endogenous growth models by Smith (1991), Pagano (1993)marginal productivity of capital and saving. All these theories have bought new dimension in the literature and challenge the exact relationship between finance and growth. Since then, numerous studies have been conducted around the globe but there have not been unanimous findings and the debate still remains unsolved. So, an attempt has been made to see the relationship between financial development and economy in Nepalese context.

The original contributions to this literature all coincide in suggesting that there is a strong positive correlation between the extent of financial development and economic growth (De Gregorio \& Guidotti, 1995). Thus, understanding the relationship may allow appropriate government policies to be implemented which will facilitate economic development. Yet empirical evidence provided so far are inconclusive and contradictory. The study is divided into empirical study aboard and Nepal.

Camba \& Camba (2020) examines the dynamic relationship of domestic credit and stock market liquidity on the economic growth using the autoregressive distributed lag (ARDL) bounds testing approach to co-integration, together with Granger causality test based on vector error correction model (VECM). The study 
reveals that ARDL model indicated a long-run relationship of domestic credit and stock market liquidity on GDP growth. The VECM also concludes a long-run causality running from domestic credit and stock market liquidity to GDP growth. At levels, domestic credit has significant short-run causal relationship with GDP growth. With regards to VECM for GDP per capita, domestic credit and stock market liquidity indicates the presence of short-run causality from stock market liquidity and GDP per capita.

Ginevičius et al., (2019)investigated the relationships between financial and economic development in the European Union countries using annual data over the period of 1998-2016. The study shows that the countries with the middle GDP per capita indicators have demonstrated the highest level of financial development while unidirectional causality running from real GDP to financial development has been detected in Denmark, Portugal and Latvia. Two-way causal relationships between financial and economic development have been observed in Luxembourg, France and United Kingdom while Finland, Germany, Czech Republic, Slovakia, Croatia and Bulgaria have supported the neutrality approach.

Osaseri \& Osamwonyi (2019) explore Stock Market development and economic growth in BRICS, Quarterly time series data for the period 1994QI to 2015Q4. The Panel Least Squares based on the fixed effect estimation was employed to determine the impact of stock market development on the economic growth of BRICS. The study indicated that there is a positive correlation between stock market development indicators and BRICS's economic growth. Further, stock market development exerts significant impact on the economic growth.

Muyambiri \& Chabaefe, (2018) evaluate the causal relationship between financial development as measured by bank-related and stock exchange and economic growth for the period of 1976 to 2014 for Botswana using multivariate Grangercausality model. The study results show that investment that drives the bankrelated and stock exchange-based financial sectors in the short run. However, the same deduction is true for bank-related financial development in the long run. Economic growth is found to Granger-cause investment and savings both in the short-run and long run. Only bank-related financial development is found to Granger-cause economic growth in Bostwana.

Tabash (2018) examines the role of Islamic banking investments in enhancing the emerging economic growth of United Arab Emirates (UAE). The study uses annual time series data to examine the relationship between the variables using autoregressive distributed lag (ARDL) framework is used for co-integration along with error correction models. The study indicates that there is a a positive and statistically significant relationship between economic growth and Islamic banks' investments in both the short-run and in the long-run as well. Further, Granger 
causality test results reveals that the causal relationship between Islamic banks' investments and the economic growth.

Onyinye, Idenyi, \& Ifeyinwa (2017) explore the effect of nonlife insurance on economic growth in Nigeria for the period 1988-2014. The study used ordinary least square regression for the testing of the hypotheses. The findings of the study revealed that non-life insurance penetration had appositive and substantial effect on the economic growth in Nigeria during the period. Furthermore, the study strongly recommended that the government should enforce compulsory coverage of health insurance for all Nigerian.

Ukpong \& Acha (2017) examine causal relationship between insurance and economic development in Nigeria. For the period 1990 -2013. The co-integration result reveals that there is a long run relationship between the gross domestic product, total life insurance premiums, total non-life premiums and total insurance investment. The regression analysis confirmed a positive relationship between total life insurance premiums, total non-life insurance premiums, total insurance investments and the gross domestic product. A unidirectional relationship has been found to be exist between GDP and total life insurance premiums.

Ghildiyal, Pokhriyal, \& Mohan (2015) attempt to investigate into the causal impact of financial deepening on economic growth in India using autoregressive Distributed Lag (ARDL). Further, using the Granger Error Correction Model (ECM) technique the study estimates the causal impact in the short run. The findings suggest that there exists an equilibrium relationship in long run between financial deepening and economic development. Results suggested that financial deepening cause's economic growth in both short run and long run. The finding of the study suggests that the government has to take effort to improve the financial deepening. Special efforts should be put to provide easy credit to private sector, stock market development and also to foster foreign trade.

\subsection{Review of Nepalese Studies}

Several studies have addressed the potential links between financial development and economic growth in case of Nepal as well. The empirical researches carried out so far suggest that there is a nexus between financial development and economic growth in India. In the Nepalese context, Gautam (2015) examine the relationship between Economic growth and financial development considering a time series data from 1975 and 2012. The study used Augmented Dickey-Fuller and Philips-Perron tests to test for the existence of unit root, Co-integration test to examine long run relationship and Granger Causality test to find out causal relationship. In addition, vector error correction method has been applied to find out the speed of adjustment and the dynamics of relationship. The finding of the empirical evidence confirms that the financial development causes economic 
growth. In fact, financial development is the cause for economic growth in terms of short-term dynamics, while economic growth sustains financial development in the long-run.

Paudel et. Al. (2018) explore the financial development and Economic growth in Nepal considering the data from 1975 to 2015 using time series data. The finding of the study established the relationship that financial development led to economic growth. The real sectors indicator like consumer price index (CPI) has more impact on real gross domestic product (GDP) than the financial development indicators as measured by M2Y and CPY. The study further predicts that negative co-integrating relationship between trade openness and GDP. Bidirectional causality has been found between broad money supply to GDP ratio and real GDP while unidirectional causality of PIY and CPI.

Bista (2018) examine the relationship between stock market development and economic growth in Nepal taking a 22 years data from 1993 to 2014 using Autoregressive distributed lag (ADRL) bound testing approaches for cointegration analysis and Granger Causality test to examine the direction. The study revealed that market capitalization has a significant impact on GDP per capita of Nepal both in long run and short run while inflation has negative and significant impact. Granger Causality result reveals that there is a bidirectional causality between market capitalization and economic growth in Nepal.

Study by Shrestha (2018) on co-integration relation between macroeconomic variables and the stock market reveals that there exists a long run equilibrium among the macroeconomic variables and stock index. The result of Granger Causality test indicated that there exists no causal relationship between stock market index and macroeconomic variables in Nepalese stock market.

Paudel and Acharya (2020) examine the role of financial development and economic growth in Nepal employing Autoregressive distributed lag (ARDL) approach of co-integration using time series data for the period from 1965 to 2018. The study develop a model with five proxies of financial development (broad money, domestic credit to private sector, total credit from banking sector, capital formation, and foreign direct investment); and econometrically test their contribution in economic growth. The finding of the study shows that financial development causes to economic growth substantially, except in the case of foreign direct investment. Methodology

\subsection{Research Gap}

Based on the review of literature empirical studies have resulted contradictory findings. Investigating a multivariate causal relationship between bank-related, stock exchange-based and insurance related financial development in regard to 
Nepalese context seems to have not been tested creating an existing gap. Thus, this study attempts to take an advantage of the multivariate causality analysis framework using the autoregressive distributed lag bounds testing approach to assess such a relationship between financial development and economic development. This study hopes to add on empirical evidence to resolve this controversy. The economy of Nepal for the study as it remains one of the smallest countries in terms of economic size among the south Asia. Nepal being developing country is chosen because it may shed light in the relationship between finance and growth.

\subsection{Research Methodology}

The conventional method in solving the causality examines the predictive content of the data in time series. This method involves regressing growth or finance indicators with lagged finance indicator and lagged growth indicator and then apply $\mathrm{F}$ test in hypothesis testing. This method can test for finance causes growth; growth causes growth, bi-directional causality or no causality(Boon, 2005). This study employs causality test to see the casual relationship using following equations.

The Granger causality method involves running the following two regression models:

$$
\begin{aligned}
& Y_{i}=\sum_{i=1}^{m} a_{i} F_{t-i}+\sum_{j=1}^{n} \beta_{j} Y_{t-j}+\varepsilon_{1 t} \\
& F_{t}=\sum_{i=1}^{m} \gamma_{i} F_{t-i}+\sum_{j=1}^{n} \delta_{j} Y_{t-j}+\varepsilon_{2 t}
\end{aligned}
$$

where $\mathrm{Y}$ is an indicator of economic development, $\mathrm{Ft}$ is an indicator of financial development and e1t and e2t re the disturbances which are assumed to be uncorrelated as if error terms are correlated then there autocorrelation problem arises.

In case if economic agents anticipate that financial or banking crisis is going to happen in the near future it will have an adverse affect in the economic. The economic growth becomes slower and possibly turns into negative growth causing series problems in a country.

In this framework, there are four possible cases:

Case 1: Unidirectional causality from $F$ to $Y$. This is indicated if $\Sigma \mathrm{i} 0$ and $\Sigma \mathrm{j}=0$ this outcome supports the view of Schumpeter. 
Case 2: Unidirectional causality from $\mathrm{Y}$ to $\mathrm{F}$. This is indicated if $\Sigma \mathbf{i}=0$ and $\Sigma \mathrm{j} 0$ this outcome is consistent with the view of Robinson.

Case 3: Bilateral causality. This is indicated if $\Sigma \mathrm{i} 0$ and $\Sigma \mathrm{j} 0$ this outcome supports both Schumpeter and Robinson.

Case 4: Independence. This is indicated if $\Sigma i=0$ and $\Sigma j=0$. This is consistent with the view of Lucas.

This type of causality test is only suitable if both data series are stationary in case of non-stationary data appropriate level of differencing must be taken to make the series stationary before the test. But Granger (1988) has pointed out that complication will arise if the two series are cointegrated. By differencing the series alone may actually lead to specification bias of the model that produce spurious results. The appropriate method is to convert the model into an error correction model (ECM) framework by including an error correction term. In the models below, and are the estimates from the cointegrating vector and the term in parenthesis is the error correction term (Boon, 2005, p3).

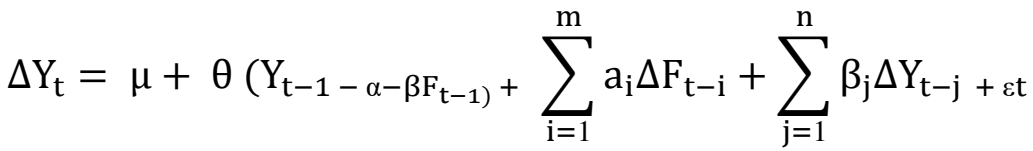

$$
\begin{aligned}
& \Delta \mathrm{F}_{\mathrm{t}}=\mu+\phi\left(\mathrm{Y}_{\left.\mathrm{t}-1-\alpha-\beta \mathrm{F}_{\mathrm{t}-1}\right)}+\sum_{\mathrm{i}=1}^{\mathrm{m}} \gamma_{\mathrm{i}} \Delta \mathrm{F}_{\mathrm{t}-\mathrm{i}}+\sum_{\mathrm{j}=1}^{\mathrm{n}} \delta_{\mathrm{j}} \Delta \mathrm{Y}_{\mathrm{t}-\mathrm{j}+\varepsilon \mathrm{t}}\right.
\end{aligned}
$$

When Yt and Ft are cointegrated, Ft can Granger cause Yt in two ways. One is through the lagged short run dynamic terms $\Sigma 0$ and this can be tested using $\mathrm{F}$ test. The other is through the lagged error correction term if 0 and this can be tested using t- test. This link also represents the long run dynamics between finance and growth. Failure to include the error correction term with cointegrated process will result in models that are mis specified and the causality testing can lead to erroneous. The ECM based causality tests offer the additional advantage that the source of causation can be identified, in the form of either short run dynamics or long run disequilibrium adjustment.

Two methods to test for co-integration are commonly used in applied research. The first method, suggested by Engle and Granger (1987), involves using Augmented Dickey Fuller (ADF) test on the residual series of a cointegrated model. If the series are cointegrated the residual series should not have unit root. The second method, suggested by Johansen (1988), is a multivariate maximum likelihood estimation technique. It involves estimating a vector error correction model (VECM) of the form: 


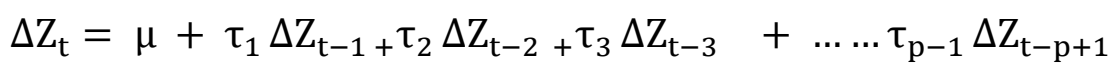

$$
\begin{aligned}
& +\Pi \mathrm{Z}_{\mathrm{t}-\mathrm{p}}+\text { et .....(3) }
\end{aligned}
$$

where $\mathrm{Zt}$ is a $\mathrm{nX} 1$ vector of $\mathrm{I}(1)$ variables indicating financial development and economic growth, $1,2, \ldots, \mathrm{p}$ and are $\mathrm{nXn}$ matrices of parameters to be estimated. Existence of co-integration implies that the matrix has non-zero rank $r<n$, equal to the number of linear combinations of the variables in $\mathrm{Zt}$ that are stationary. Two tests can be used to test for co-integration. One is the trace statistic while the other is the $\mathrm{n}$ max statistic. The statistic tests the null hypothesis of at most $\mathrm{r}$ cointegration vectors against an alternative of at least $r+1.3$

\section{MEASUREMENT AND DATA SOURCES}

As the history prevails there has been a very slow and steady growth of both financial development and economic growth of the country creating a great interest to the researcher to establish the relationship between tow. This study uses annual data for the analysis purpose as suggested by (Masih \& Masih, 1996). However, most of the prior studies seem to have use quarterly and monthly data. There are different functions performed by financial sector and they influence growth differently, so the appropriate selection of variables is key for the study. Based on the literature review the study considers three important indicators of the financial development as bank, capital market and the insurance.

In financial development the widely used variable is gross domestic product (GDP) and gross fixed capital formation is taken into consideration. The aggregate growth in economy is measured by Gross domestic product. The increase in investment can be captured by an increase in real gross fixed capital formation per capita and this is the second growth indicator. The study period chosen is from 1975 to 2019 for both series.

The problem of using aggregate financial data is that it will not explain how finance affects growth. Thus, this paper uses three major indicators of the financial development as capital market growth, banking sector development and insurance sector development. The first type is capital markets measured by market capitalization and the data available from 1994 to 2019. The second financial indicator is to represent the development of the insurance market and this is proxies by the total gross premium collected. The study period considered for the study is from 1985 to 2019. The final variable under consideration is a bank and the proxy variable used is private sector credit with data used from 1975 to 2019. The data has been retrieved from Central Bureau of Statistics (CBS), 
Nepal Rastra Bank and Beema Samiti from web and annual reports of the insurance company.

\section{RESULTS AND DISCUSSION}

The study begin with testing for unit root for the growth and financial development time series. For this purpose, unit root test namely ADF test is performed. The null hypothesis is of unit root, nonstationary, and the alternative hypothesis is the absence of unit root, stationary. Tests on all the data series are conducted first on the level and if not found significant then at the first difference. A visual inspection on the series is done to decide on the inclusion of intercept and time trend in the ADF test. The ADF test does not reject the null of a unit root for the data in levels and rejects the null for each of the differenced series. The findings imply that it is reasonable to model all of the relevant variables as nonstationary. The results are presented in table 1 .

Table: 1 ADF Test for Unit Root

\begin{tabular}{lcc}
\hline \hline Data Series & Level & 1 st difference \\
Real Gross domestic Product (GDP) & $0.1058^{* *}$ & -6.376 \\
Real Gross Fixed Capital Formation (GCF) & $1.895^{* *}$ & -6.613 \\
Stock Market Capitalization (MC) & $-0.317^{* *}$ & -3.461 \\
Insurance Premium, Insurance (IP)) & $-0.123^{* *}$ & -6.616 \\
Real Private Sector Credit, BANK (PRVT) & $-0.007^{* *}$ & -6.173 \\
\hline \hline ** denotes the rejection of unit root at 1 percent level of significant, all variables are taken as log
\end{tabular}

First of all the study has carried out the stationary test using the ADF unit root test. After conforming the stationary of the data indicating that the data is normal and the next step applied is Johanesen test of co-integration to see the direction of causation. Table 2 shows that statistics are significant at 1 percent level for none cointegrating equations. However, the results agree that there is at most a one cointegration equation in all systems. This implies that there is a cointegrating relationship between stock market development and economic development, banking sector development and economic development and insurance sector development and economic development. Once the study has found cointegrating equations, the next step is to estimate error correction model. The results of vector error correction model are presented in following section. 
Table: 2 Johansen Test for Co-integration

\begin{tabular}{|c|c|c|c|c|}
\hline \multirow[t]{2}{*}{ System } & \multicolumn{2}{|c|}{ Trace } & \multicolumn{2}{|c|}{ Eigenvalue } \\
\hline & None & At most one & None & At most one \\
\hline $\begin{array}{l}\text { GDP and Stock market growth } \\
\text { (Market capitalization) }\end{array}$ & $29.03448 * *$ & 8.718305 & $0.571090 * *$ & 0.304596 \\
\hline $\begin{array}{l}\text { GFC and Stock market growth } \\
\text { (Market capitalization, MC) }\end{array}$ & $24.98351^{*}$ & 3.841723 & $0.585594 *$ & 0.147917 \\
\hline $\begin{array}{l}\text { GDP and Insurance Market } \\
\text { growth (Insurance Premium, IP) }\end{array}$ & $34.06355^{* *}$ & 3.025565 & $0.609585^{* *}$ & 0.087606 \\
\hline $\begin{array}{l}\text { GFC and Insurance Market } \\
\text { growth (Insurance Premium, IP) }\end{array}$ & $29.36130 * *$ & 2.303089 & $0.559544^{* *}$ & 0.067411 \\
\hline $\begin{array}{lrr}\text { GDP and } & \text { Banking } & \text { sector } \\
\text { development } & \text { (private } & \text { sector } \\
\text { credit, Bank) } & & \end{array}$ & $32.6516^{* *}$ & 2.826516 & $0.500230 * *$ & 0.063619 \\
\hline $\begin{array}{lrr}\text { GFC and } & \text { Banking } & \text { sector } \\
\text { development } & \text { (private } & \text { sector } \\
\text { credit, Bank) } & & \end{array}$ & $40.71916^{* *}$ & 4.141476 & $0.572860 * *$ & 0.091821 \\
\hline
\end{tabular}

\subsection{Capital Market and Economic Growth}

The results show that error correction term is negative when GDP and GCF are dependent variables this indicates that there exist the strong co-integration relationship between market capitalization and economic development. The means short-run causality is running from market capitalization to GDP the statistics shows that lagged values of MC is significant with GDP indicating MC causes GDP in short run. The $t$ statistics values are shown in parenthesis. 
Table:3 Johansen Co-integration between Market Capitalization and Economic Growth

\begin{tabular}{lcllll}
\hline \hline $\begin{array}{l}\text { Error } \\
\text { Correction: }\end{array}$ & $\mathrm{D}(\mathrm{GDP})$ & $\mathrm{D}(\mathrm{MC})$ & $\begin{array}{l}\text { Error } \\
\text { Correction: }\end{array}$ & $\mathrm{D}(\mathrm{GFC})$ & $\mathrm{D}(\mathrm{MC})$ \\
\hline \hline ECM-1 & $-0.18739 * *$ & 1.299750 & ECM-1 & -0.121024 & 0.757468 \\
& $(-3.76390)$ & $(-1.28031)$ & & $(-1.57341)$ & $(-1.7801)$ \\
$\mathrm{D}(\mathrm{GDP}(-1))$ & $0.356845^{*}$ & 0.881752 & $\mathrm{D}(\mathrm{GFC}(-1))$ & 0.113544 & -1.77191 \\
& $(-2.18962)$ & $(-0.26534)$ & & $(-0.31219)$ & $(-0.88065)$ \\
D(GDP(-2)) & 0.053915 & 6.659168 & $\mathrm{D}(\mathrm{GFC}(-2))$ & -0.02416 & -1.35617 \\
& $(-0.3269)$ & $(-1.98011)$ & & $(-0.10366)$ & $(-1.05175)$ \\
D(MC(-1)) & 0.009674 & $0.608412^{*}$ & $\mathrm{D}(\mathrm{MC}(-1))$ & $0.131757 * *$ & 0.338050 \\
& $(-0.79434)$ & $(-2.45001)$ & & $(-2.71819)$ & $(-1.26065)$ \\
D(MC(-2)) & $-0.05096 * *$ & -0.10642 & D(MC(-2)) & -0.02963 & 0.018563 \\
& $(-4.05755)$ & $(-0.41554)$ & & $(-0.45036)$ & $(-0.0510)$ \\
\hline \hline R-squared & 0.364715 & 0.191088 & R-squared & 0.471735 & 0.134151 \\
Adj. R-squared & 0.223541 & 0.011330 & Adj. R-squared & 0.354342 & -0.05826 \\
\hline \hline
\end{tabular}

** denotes 1 percent level of significance, * 5 Percent level of significance

\subsection{Insurance sector development and Economic Growth}

The results show that error correction term is negative for both GDP and GCF. This reinforces the co-integration result that there is cointegrating relationship between insurance premium and economic development. However, the result shows no evidence of causality between insurance premium and economic development in short-run.

Table 4 Johansen Co-integration between Insurance and Economic Growth

\begin{tabular}{lcclcc}
\hline \hline $\begin{array}{l}\text { Error } \\
\text { Correction: }\end{array}$ & $\mathrm{D}(\mathrm{GDP})$ & $\mathrm{D}(\mathrm{IP})$ & $\begin{array}{l}\text { Error } \\
\text { Correction: }\end{array}$ & $\mathrm{D}(\mathrm{GFC})$ & $\mathrm{D}(\mathrm{IP})$ \\
\hline \hline ECM-1 & $-0.028995 * *$ & $-0.15574 * *$ & ECM-1 & $-0.000482 *$ & $-0.001542 * *$ \\
& $(-3.94244)$ & {$[-4.65737)$} & & $(-2.02696)$ & $(-5.88651)$ \\
$\mathrm{D}(\mathrm{GDP}(-1))$ & -0.158855 & -0.675362 & $\mathrm{D}(\mathrm{GFC}(-1))$ & -0.103337 & -0.15807 \\
& $(-0.88117)$ & $(-0.82394)$ & & $(-0.62772)$ & $(-0.87206)$ \\
$\mathrm{D}(\mathrm{IP}(-1))$ & 0.012251 & -0.227204 & $\mathrm{D}(\mathrm{IP}(-1))$ & 0.019713 & -0.194322 \\
& -0.29631 & $(-1.20864)$ & & -0.11914 & $(-1.06667)$ \\
\hline \hline R-squared & 0.069881 & 0.038660 & R-squared & 0.041617 & 0.049173 \\
Adj. R-squared & 0.007873 & -0.025429 & Adj. R-squared & -0.022275 & -0.014216 \\
\hline \hline
\end{tabular}

** denotes 1 percent level of significance, * 5 Percent level of significance 


\subsection{Banking sector development and Economic Growth}

The results show that error correction term is negative when GDP is dependent variable. This reinforces the co-integration results that there is cointegrating relationship between banking sector development and economic growth. The result also shows that lagged value of GDP is significant at 1 percent level. It shows that short-run causality is running from GDP to banking sector development.

Table 5 Johansen Co-integration between Bank and Economic Growth

\begin{tabular}{llllcc}
\hline \hline $\begin{array}{l}\text { Error } \\
\text { Correction: }\end{array}$ & D(GDP) & D(PRVT) & $\begin{array}{l}\text { Error } \\
\text { Correction: }\end{array}$ & D(GDP) & D(PRVT) \\
\hline \hline ECM-1 & $-0.294278 * *$ & $1.073469 * *$ & ECM-1 & 0.119947 & $0.365288^{* *}$ \\
& $(-2.65961)$ & $(-2.84951)$ & & -0.80212 & -2.7906 \\
D(GDP(-1)) & -0.117313 & -0.545306 & D(GFC(-1)) & $-0.391588^{*}$ & -0.234072 \\
& $(-0.79259)$ & $(-1.08210)$ & & $(-1.98834)$ & $(-1.35777)$ \\
D(PRVT(-1)) & 0.007374 & 0.359667 & D(PRVT(-1)) & -0.054767 & 0.134137 \\
& $(-0.17949)$ & -2.57137 & & $(-0.37923)$ & $(-1.06107)$ \\
C & $0.046832 * *$ & $0.149103 * *$ & C & $0.102139 * *$ & $0.183419 * *$ \\
& $(-4.9683)$ & $(-4.64594)$ & & $(-3.00535)$ & $(-6.16542)$ \\
\hline \hline R-squared & 0.215044 & 0.210077 & R-squared & 0.098765 & 0.203763 \\
Adj. R-squared & 0.154662 & 0.149313 & Adj. R-squared & 0.029439 & 0.142514 \\
\hline \hline
\end{tabular}

** denotes 1 percent level of significance, * 5 Percent level of significance

\section{CONCLUSION}

This study investigates the direction of relationship between financial indicators and growth indicators in Nepalese context. The result of the study reveals that there is cointegrating relationship between market capitalization and economic development with short-run causality is running from market capitalization to GDP. In regard to insurance market, error correction term is negative and significance for both GDP and GCF indicating there is cointegrating relationship between insurance market and economic development. However, the result shows no evidence of causality between insurance premium and economic development in short-run. The negative relation between bank and GDP reinforces that there is a cointegrating relationship between banking sector development and economic development. The result also shows that lagged value of GDP is significant indicating there is a short-run causality is running from GDP to banking sector development

Thus, the study concludes, there is a presence of co-integration, the causality usually occurs in the long run dynamics (the lagged error correction term. The results depict that the relationship between financial development and economic growth is more likely to be a long term one. 


\section{REFERENCES}

Bayar, Y., Kaya, A., \& M. Yildirim. 2014. Effects of Stock Market Development on Economic Growth: Evidence from Turkey. International Journal of Financial Research, 5(1), 93-100. https://doi.org/10.5430/ijfr.v5n1p93

Gautam, B. P. 2015. Role of Financial Development in Economic Growth of Nepal: An Empirical Analysis. NRB Economic Review, 27(1), 1-16.

Bista, P. J. 2018. Stock Market Development and Economic Growth in Nepal: An ARDL Representative, , 1(1), 76-92.

Boon, T. K. 2005. Do commercial banks, stock market and insurance market promote economic growth? An analysis of the Singapore economy. Nanyang Technological University, School of Humanities and Social Studies, Working Paper. Retrieved from http://doi=10.1.1.671.2634

Camba Jr, A. C., \& A. L. Camba. 2020. The dynamic relationship of domestic credit and stock market liquidity on the economic growth of the Philippines. The Journal of Asian Finance, Economics, and Business, 7(1), 37-46. https://doi.org/10.13106/jafeb.2020.vol7.no1.37

De Gregorio, J., \& P. E. Guidotti. 1995. Financial development and economic growth. World development, 23(3), 433-448. https://doi.org/10.1016/0305750X(94)00132-I

Demetriades, P. O., \& K. A. Hussein. 1996. Does financial development cause economic growth? Time-series evidence from 16 countries. Journal of development Economics, 51(2), 387-411.

Graff, M. 1999. Financial Development and Economic Growth-A new empirical analysis. Dresden Discussion Papers in Economics, (5/99).

Goldsmith, R. 1969. Financial Structure and Development, New Haven, CT, Yale University Press.

Ghildiyal, V., Pokhriyal, A., \& A. Mohan. 2015. Impact of Financial Deepening on EconomicGrowth in Indian Perspective: ARDL Bound Testing Approach to Co-integration.Asian Development Policy Review, 3(3), 49-60

Ghildiyal, V., Pokhriyal, A. K., \& A. Mohan. 2015. Impact of financial deepening on economic growth in Indian perspective: ARDL bound testing approach to cointegration. Asian Development Policy Review, 3(3), 49-60 https://doi.org/10.18488/journal.107/2015.3.3/107.3.49.60

Levine, R. 1997. Finance, Entrepreneurship and Growth. Journal of Monetary Economics, 1993b, 32, 513-42. 
Lucas, R. E. 1988. World Devziopment Report. Journal of Monetary Economics, 22(February), 3-42. https://doi.org/10.1016/0304-3932(88)90168-7

Masih, R., \& A. M. Masih. 1996. Macroeconomic activity dynamics and Granger causality: New evidence from a small developing economy based on a vector error-correction modelling analysis. Economic Modelling, 13(3), 407-426. https://doi.org/10.1016/0264-9993(96)01013-9

McKinnon, R. 1973. Money and capital in economic development, 1st edn. the Brooking Institution. Washington DC.

Muyambiri, B., \& N. N. Chabaefe. 2018. The Finance - Growth Nexus in Botswana: A Multivariate Causal Linkage. Dutch Journal of Finance and Management, 2(2). https://doi.org/10.20897/djfm/2634

Nyasha, S., \& N. M. Odhiambo. 2015. Banks, stock market development and economic growth in South Africa: a multivariate causal linkage. Applied Economics Letters, 22(18), 1480-1485. https://doi.org/10.1080/ 13504851.2015.1042132

Onwumere, J. U. J., Ibe, I. G., Okafor, R. G., \& U. B. Uche. 2012. Stock market and economic growth in Nigeria: Evidence from the demand-following hypothesis. European Journal of Business and management, 4(19), 1-9.

Onyinye, N. G., Idenyi, O. S., \& A. C. Ifeyinwa. 2017. Effect of capital formation on economic growth in Nigeria. Asian Journal of Economics, Business and Accounting, 1-16. https://doi.org/10.9734/ajeba/2017/36075

Osaseri, G., \& I. O. Osamwonyi. 2019. Impact of stock market development on economic growth in BRICS. International Journal of Financial Research, 10(1), 23-30. https://doi.org/10.5430/ijfr.v10n1p23

Pagano, M. 1993. Financial Markets and the Macroeconomy Financial markets and growth An overview. European Economic Review, 37(2-3), 613-622. Retrieved from http://ideas.repec.org/p/wpa/wuwpge/0111001.html

Patrick, H. T. 1966. Financial development and economic growth in underdeveloped countries. Economic development and Cultural change, 14(2), 174-189

Paudel, R. C. \& C. P. Acharya. 2020. Financial Development and Economic Growth in NEpal: NEw intuitions from a Time Series Causality Method: Evidence from Nepal Economic Review, Nepal Rastra Bank, 32(1), 16-31

Paudel, U. \& C. S. Bhatta \& U. Khatri. 2020. Financial Development and Economic Growth: Evidence from Nepal. Journal of Social Science., 14(1), 116-123 
Robinson, J. 1979. The Generalization of the General Theory. In The Generalisation of the General Theory and Other Essays (pp. 1-76). Palgrave Macmillan, London.

Schumpeter, J.A. 1911. Theorie der wirtschaftlichen Entwicklung . Theory of Economic Development]. Munich: Duncker \& Humblot.

Shaw, E. S. 1973. Financial deepening in economic development.

Shrestha, M. P. 2018. Cointegtrating relationship between Macroeconomic variables and the stock market: Evidence from Nepal Stock Exchannge (NEPSE); The Nepalese Management Review, 1(1), 171-186.

Solow, R. M. 1956. A contribution to the theory of economic growth. The quarterly journal of economics, 70(1), 65-94.

Tabash, M. I. 2018. Islamic financial investments and economic growth evidence from emerging economy, United Arab Emirates. International Journal of Economics and Business Research, 15(1), 125-139. https://doi.org/10.1504/ IJEBR.2018.10008872

Ukpong, M. S., \& I. A. Acha. 2017. Insurance and Economic Development in Nigeria: Co-Integration and Causality Analysis. Scholedge International Journal of Management \& Development ISSN 2394-3378, 4(4), 28. https://doi.org/10.19085/journal.sijmd040401 